\title{
Confucius' Thought of Teaching without Classification and Its Enlightenment to Modern Teachers
}

\author{
Wang Fan \\ China Jiliang University \\ Hangzhou, China
}

\begin{abstract}
Confucius is a great educator in the history of education of the Chinese nation. He is known as the "teacher of all ages". The thought of "teaching without classification" is an important part of Confucius' educational thought system and has great significance in the history of China's educational development: it is the origin of the modern idea of equal right to education; it is the germination of lifelong education theory not to choose the object of education by age; it is the educational manifestation of Confucius' thought of "benevolence" and reflects the humanistic care of education. Many educational concepts of modern education are closely related to Confucius' thought of "teaching without classification". By studying Confucius' thought of "teaching without classification", we can inspire modern teachers to change their educational concepts and improve their professional quality in education and teaching, respect students' personality and develop a responsible attitude, recognize students' differences and pay attention to teaching students in accordance with their aptitude.
\end{abstract}

Keywords-Confucius; Teaching without Classification; Teachers

\section{INTRODUCTION}

"Teaching without classes" is the greatest thought in Confucius\&apos;educational thought system. Over 2500 years ago, the thought of "teaching without classes" has important enlightenment significance for contemporary Chinese teachers in education and teaching.

\section{Confucius' Thought OF "TEAChING Without CLASSIFICATION"}

"Teaching without Classification" comes from the Analects of Confucius. There has been a lot of controversy about its interpretation in academic circles. The focus of divergence lies in the understanding of "Classification".

Everyone interprets teaching as two kinds of viewpoints: one is that no matter who is noble or humble, moral character, country or age, as long as you have the desire to learn, you can educate him by "self-discipline or above".Second, education is a prerequisite or means, not a result.People were originally classified, for example, some were expensive, some were cheap, some were intelligent, some were foolish, and some were of high moral character.Some people have low morality, but these differences can be eliminated through education.
Confucius\&apos;thought of "teaching without classes" is embodied in the following points:

1.Education is acceptable to students, whether valuable or cheap.

2.Education is available regardless of intelligence or temperament.

3.Education is acceptable regardless of region or country.

4.Education is acceptable regardless of age or age.

\section{The Positive SignificAnCE OF CONFUCIUS' THOUght OF "TEACHING WITHOUT CLASSIFICATION"}

As a famous educator in ancient China, Mao Zedong once commented on Confucius\&apos;s saying that "enlarging the scope of education and having the character of the people". Confucius\&apos;s educational thought is still valuable for today\&apos;s education.

A. Breaking the Educational Monopoly of the Aristocracy is the beginning of the idea of educational equity.

1) Confucius' thought of "Teaching without Classification" is the origin of modern thought of equal right to education

Confucius\&apos;thought of "teaching without classes" can be educated regardless of wealth, wealth, wealth, intelligence and temperament, region and country, and age gap, which is very similar to the concept of equal right to education now.Confucius founded private schools and enrolled students of different origins into schools, which broke the situation of "learning in government" at that time. Confucius\&apos; educational slogan of "teaching without classes" made it clear that the right of civilians to education.

2) Confucius; thought of "teaching without classification" embodies the ultimate goal of education is to promote everyone's development.

The idea of "teaching without classes" conveys that everyone has the right to receive education. Education does not restrict students because of their age, talent, intelligence level, age, region and country, and high or low birth. In this way, it provides a way for everyone to develop. People can make up for congenital deficiencies through acquired learning.Among Confucius\&apos;students, there are also "decadent wood can 
not be carved", but Confucius did not treat such students differently, but actively guided them.Confucius was inspired by slaughter. He could not listen to his words and believe in his deeds, but listen to his words and observe his actions.Confucius\&apos;s "teaching without classes" is just like this, believing that everyone can be educated, and through education to achieve the goal of human development.

\section{B. Not choosing the object of education by age is the} germination of the theory of lifelong education.

Although Confucius did not explicitly put forward the concept of "lifelong education", his "teaching without classes" reflects life-long education from the side.Confucius\&apos;s requirement of "self-cultivation" is similar to that of "lifelong education".Confucius said, "I have five tenths, but I am determined to learn.A man should be independent at the age of thirty.At forty, I had no doubts.At fifty, I knew the decrees of heaven.At sixty, my ear was an obedient organ for the reception of truth.Confucius is the practitioner of "lifelong education".Confucius did not restrict the behavior of educational objects by age. It not only embodied the idea of educational equity, but also the germination of the theory of "lifelong education".There is an inherent consistency between the theory of "lifelong education" and the thought of "teaching without classes".

\section{Confucius' thought of benevolence is manifested in education, which embodies the humanistic concern of education.}

The thought of "teaching without classes" is a manifestation of the theoretical system of "benevolence" at the educational level, and has a strong humanistic concern.Confucius said in The Analects of Confucius Yang Goods that "sex is similar, habits are far from each other". That is to say, everyone is born with the same nature, but because of the acquired life experience, the temperament of each other changes.Under the guidance of the educational policy of "teaching without classes", students can be educated in different regions, countries, intellectuals, temperaments and ages. However, students who are recruited will have different qualities. Therefore, different educational methods should be adopted to teach students in accordance with their aptitude for different students. This also reflects the Confucian emphasis on students and the humanistic concern of education.

\section{The ENLIGHTENMENT OF CONFUCIUS' THOUGHT OF "TEACHING WITHOUT CLASSIFICATION" TO MODERN TEACHERS}

The fundamental purpose of modern education is to promote the free and comprehensive development of every student. Teachers play an irreplaceable role in this process.As an important part of Confucius\&apos; educational thought, the thought of "teaching without classes" has a great reference for modern teachers\&apos; education and teaching.

\section{A. Transforming educational concepts and improving professional quality}

Russian educator Ushenski once said, "Education is a purposeful and conscious process of cultivating harmonious development of human beings."Education is a science as well as an art. The change and renewal of teachers\&apos;educational concepts have a very important influence on the cultivation of students\&apos; innovative spirit and practical ability and the promotion of social progress.In terms of changing educational concepts, the thought of "teaching without classes" can provide many beneficial educational inspirations, insist on "using the past for the present" and use dialectical methods to analyze Confucius\&apos;idea of "teaching without classes", so as to ultimately achieve the goal of improving teachers\&apos; professional quality.

1) Establish the educational belief that everyone can be successful

Confucius\&apos; theory of human nature is the starting point of the thought of "teaching without classes" and the theoretical basis of Confucianism to promote personal development.Human nature is good, everyone has inherent moral reason, "benevolence" is the highest summary of virtue.A person may have different innate endowments and living environment, but the intrinsic value and dignity are the same. They all have the potential and possibility to be superior to animals, that is, everyone has the potential to be successful.For teachers, to establish the educational belief that everyone can become a talent, we should believe that students can become a talent. There are thousands of ways to become a talent in life. We can\&apos;t emphasize students\&apos;achievements blindly and judge heroes by achievements.In fact, a person\&apos;s performance is affected by many factors. Students\&apos;memory, analysis and judgment ability, imagination and so on are directly related to students\&apos; performance.It is neither desirable nor desirable for a teacher to judge a student by a whip of his grades.Finding the shining point of students, finding their strengths, guiding students to set up their own life goals and find their own direction of success according to their interests are what teachers should do after they have established the educational belief that everyone can become successful.

2) Establish the educational thoughts of "education for reaching people" and "education fora Adults"

Although everyone has the potential to become a talent, not everyone can become a talent.Confucius\&apos; theory of human nature holds that education is necessary to achieve "benevolence", and the way to become a person is education.Education is not an end in itself. Promoting students\&apos;all-round development is the real purpose of education.The ultimate aim of Confucius\&apos;s thought of "teaching without classes" is to eliminate the differences between people through education and realize the "dead class"."Education for adults" is to let students know the truth of being human through education. As a modern teacher, it is not only to impart professional knowledge, but also to teach students the truth of being human, to understand what can be done, what can not be done, and to enhance students\&apos;ideological and moral literacy."Education to achieve people" is to enable students to improve themselves, more able to use the instructions they have learned to achieve their own value in life.Teachers should have a thorough understanding of students, analyze their own strengths and weaknesses, and then proceed to "prescribe the right remedy".What teachers need to do on the way of 
students\&apos;talent is to guide students and let them find their own way.

\section{3) Establish the concept of equal education}

Because of their different gifts and environments, students\&apos;academic performance is also very different.But education is equal and everyone has the right to education. This is the concept of equal education at the legal and national level.At the individual level, as a teacher, we should also set up the concept of equal education. The fundamental thing is to teach students to have a just heart. We should not treat students differently because of their grades or disgust because of their stupidity.Teachers should set up the view of equality and benevolence.The thought of "teaching without classes" has strong humanistic feelings, and its essence is people-oriented and students-oriented.Confucius, as a teacher, faced with students of all levels, did not blindly choose talented students to teach. Other students let themselves go as much as they learned.Instead, we should have the heart to learn and bring a bacon to learn.In the current educational environment, teachers have no right to choose students, but there is still a lot of room for them to choose to teach.In this case, teachers need to set up an equal education concept, treat students equally instead of colored glasses.

\section{B. Respect students' personalities and develop a responsible attitude}

Because of the different growth environment and life experience, students\&apos;thinking ability is independent. Children are not puppets in the hands of teachers. Students have their own consciousness and judgment ability. They must respect students\&apos; personality and develop a responsible attitude.

\section{1) Care for and care for every student and understand what} they think and think

It is an important teaching method for Confucius to teach students in accordance with their aptitude according to their different natures. However, if we want to use this teaching method, or to implement it, we need to have a very profound understanding of students.Under modern education mode, students spend more time in school than at home, so understanding students can not only rely on communicating with parents, but also need teachers to know more about students in their daily study and life, to make clear what students think and what they think. Only by knowing what students think and where their troubles lie in their study and life, can students be targeted.To guide and promote the healthy growth of students.Although there are many ways for teachers to understand students, not all of them are suitable for students. Students have different personalities and some of them are suitable for this kind of students, but they are not necessarily suitable for another kind of students. To achieve the best results, teachers need to have the art of communication. On the basis of communicating with students, they need to understand what students think and think

2) Establish a good teacher-student relationship and develop a conscientious and responsible teaching attitude

The Analects of Confucius embodies the relationship between teachers and students everywhere.The well-known "three people walk, there must be my teacher Yan" is the embodiment of this relationship. Teachers do not always have to be first-class students, in many ways can learn from each other.In the process of teaching students, teachers can also verify their knowledge and ways of doing things and establish good teacher-student relationship. Teachers need to cultivate a humble attitude and seek truth from facts.In teaching students, "Knowing is knowing".Teachers should cultivate a conscientious and responsible teaching attitude and treat students equally. Confucius criticized Zaiyu for "decaying wood can not be carved, and the wall of dung can not be dirty." In fact, Confucius was angry when he saw Zaiyu sleeping in the daytime and did not study. On the other hand, he hoped that the students could study steadily and not waste time.In modern society, students will have a lot of confusion in their study and life. So, for teachers, they need to learn how to strip cocoons and answer students\&apos;questions pertinently.Teachers need to be friends with students and care about students\&apos;life and learning.

\section{Recognize the differences among students and pay attention} to teaching students in accordance with their aptitude

Through the growth of crops, Confucius found that "there is a man who does not show his seedlings!"Inspired by the fact that students are also individually different, there is no unified teaching model in the teaching process.It is "teaching according to one\&apos;s aptitude" and "teaching without class".

\section{1) Acknowledge students' individual differences}

Everyone has the right to education, that is to say, education teaches all people without restrictions, but everyone is different and needs education to eliminate differences.To educate these different students, we need to adopt different ways for different students.Acknowledging students\&apos;individual differences is the premise and fundamental guarantee of "teaching students in accordance with their aptitude".Students are different, regardless of family background, intellectual level and psychological quality will have a variety of differences.As a teacher, we need to treat these students equally, neither conceal these differences, but take it for granted that students are the same, so as to do everything, but also need to teach students in accordance with their aptitude, from the differences of students to find the shining point of students\&apos;success, and guide students to develop themselves.

2) Guide students to establish learning direction according to their situations

According to the students\&apos;situation, students should establish their own development direction.Confucius, facing many disciples, is not a unified requirement for students to ultimately achieve what kind of goals, but to take into account the actual situation and ability of students for educational guidance, so that students according to their own situation, determine their own learning direction.Confucius\&apos;s way of observing students is to "see what they are doing, what they are doing, what they have done in the past, and where their hearts are.Observing students in an all-round way and making a thorough understanding and careful analysis of students can improve the pertinence and efficiency of teaching.In the current education and teaching, teachers need to take a variety of ways to understand students as much as possible.In modern society, 
the way of communication between students and teachers is no longer a simple linear way of communication, but a three-dimensional, all-round way of communication.As a teacher, we need to try to use a variety of ways to learn more about students, to achieve the effect of "teaching students in accordance with their aptitude", so that students know what their learning direction is, and then under the guidance of teachers, work towards the direction to promote students to become talented.

Confucius'educational thought has played an irreplaceable role in the development of education in China for thousands of years. As the core of Confucius' educational thought, the thought of "teaching without classes" reflects Confucius'pursuit of fairness and equality in education. It also improves the ideological and moral level of modern teachers, improves the quality of teaching and strengthens the relationship between teachers and students. Ability, thus promoting social education equity, improving national quality, providing power for building socialism with Chinese characteristics, and providing talent support for realizing the Chinese dream of great rejuvenation of the Chinese nation.

\section{REFERENCES}

[1] Zhang Yanying. Translations and Annotations of the Analects of Confucius [M]. Beijing: Zhonghua Bookstore, 2007.

[2] Sima Qian. Historical Records [M]. Beijing: Zhonghua Publishing House, 1959.

[3] [Song] Zhu Xi. Annotations of Chapters and Sentences in Four Books [M]. Beijing: Zhonghua Publishing House, 1983:169-170.

[4] [Wei] He Yan. Collection of Confucian Analects [M]. Beijing: Zhonghua Bookstore, 1998:70.

[5] Yang Bojun. Translations and Annotations of the Analects of Confucius [M]. Beijing: Zhonghua Publishing House, 2012:238
[6] He Yan (Note), Huang Kan (Shu). Analects of Confucius (M). Beijing: Commercial Press, 1937:226.

[7] [Han] Sima Qian. Historical Records [M]. Changsha: Yuelu Book Society, 2004:566-600.

[8] He Xiaowu. On Confucius\&apos;Educational Thought and Its Enlightenment to Modern Education [J]. China Science and Education Innovation Guide, 2012 (1): 8.

[9] Song Shulin, The Analects of Confucius and Confucius\&apos; educational philosophy $[\mathrm{J}]$. Primary and secondary education, 2016 (8): 12.

[10] Li Weili. Confucius\&apos;Thought of "Teaching without Classification" and its Contemporary Value [J]. Hebei Enterprise, 2016 (10): 98-99.

[11] Xia Lianxian, Gao Zheng. "Teaching without class" or "Teaching needs with class" [J]. Primary and secondary school principals, 2017 (12): 6.

[12] Tang Yizheng. On Confucius\&apos;Educational Thought of "Teaching without Classification"[J]. Lantai World, 2015 (10): 47-48.

[13] The Progressive Significance and Limitation of Confucius\&apos;Thought of "Teaching without Classification"[J]. Industry and Science Forum, 2016 (10): 195-196.

[14] Wang Shiwei. [J]. New Explanation of "Teaching without Classification" Shanghai Educational and Scientific Research, 2014 (2): 34-35.

[15] Zhuangziyuan. [J] Academia, 2015 (12): 118-124.

[16] Luo Cheng. [J]. University Education, 2013 (8): 120-121.

[17] The Enlightenment of Liu Weijie\&apos;s Confucius Educational Thought on Contemporary Physical Education [D]. Taiyuan University of Technology, 2013.

[18] Zhang Tianqi. Confucius\&apos;Educational Thought and Its Contemporary Value [D]. Jilin University, 2017.

[19] Enlightenment of Chen Shan. Confucius\&apos;Educational Thought on Physical Education [D]. Hebei Normal University, 2013.

[20] Xiyanfeng. Research on Confucius\&apos;Thought of Educational Equity [D]. Shanxi University, 2012.

[21] W. Dilthey. Introduction of Human Studies [J]. Journal of Inflammation-London, 1988 (5): 55

[22] Alexnader, J.C. Culture and Societ [M]. Cmabridge University Press, 1990 